UNRAM Law Review is licensed under a Creative Commons Attribution 4.0 International License, which permits unrestricted use, distribution, and reproduction in any medium, provided the original work is properly cited. p-ISSN: 2548-9267 | e-ISSN : 2549-2365, Open Access at : http://unramlawreview.unram.ac.id/index.php/ulr

\begin{tabular}{|c|c|c|c|c|}
\hline Volume & Issue & Page & April & p-ISSN: 2548-9267 \\
\hline 3 & 1 & $7-14$ & 2019 & e-ISSN : 2549-2365 \\
\hline
\end{tabular}

\title{
Legal Politics Of State Assets Recovery By In Absentia Court In Act Number 20 Year 2001 Concerning Eradication Against Corruption
}

\author{
Titin Nurfatlah \\ Program Studi Magister Ilmu Hukum Program Pascasarjana \\ Universitas Mataram \\ Email : titinnurfatlah11@gmail.com \\ Gina Meilinda \\ Program Studi Magister Ilmu Hukum Program Pascasarjana \\ Universitas Mataram \\ Email : gmeylinda@gmail.com \\ Fifi Rosalina \\ Program Studi Magister Ilmu Hukum Program Pascasarjana \\ Universitas Mataram \\ Usnadi \\ Program Studi Magister Ilmu Hukum Program Pascasarjana \\ Universitas Mataram
}

\begin{abstract}
State assets recovery is an important part of the law enforcement on corruption crimes. Therefore state assets recovery shall be state's legal politics. This study intended to find out the Indonesian legal politics of state asset recovery through in absentia court. Method of this study is normative research and used statute approach and conceptual approach. Based on the analysis can be concluded that in absentia court have enumerated in Indonesian Law Regarding Eradicating Against Corruption. This is in line with the legal politics in the decree Of Indonesian People's Consultative Assembly which emphasizes the acceleration of legal processes in criminal acts of corruption.
\end{abstract}

\section{Keywords : Legal Politics; in absentia; asset recovery.}

\section{INTRODUCTION}

National legal politic is a fundamental policy of state agent (Republik Indonesia) in legal plane, that will, being and have already applied, that relies from value applied in society to achieve national ideas. ${ }^{1}$ Indonesia state agent that have an authority to make policy in the level of Act are President and House of Representatives. House of Representatives as a body that represent all Indonesian Peoples shall know value in Indonesia, while president as a state organ that have an authority to lead government, shall cooperate in arranged state legal policy that enumerated in an Act. This is including an Act regarding corruption, that not only punished the corruptor but also can recover state assets.

\footnotetext{
${ }^{1}$ Imam Syaukani \& A.Ahsin Thohari. (2006). Dasar-dasar Politik Hukum, Jakarta: PT. Raja Grafindo Persada, p 58.
} 
From a legal point of view, corruption crime in sketchy includes the following substances: the acts against the law, authority abusement, opportunity, or, medium, to enrich themself, others, or corporations, harm state's finances or the economic matters of country. ${ }^{2}$ Corruption is a serious crimes since negative effect of this crime impacted all plane of life. This crime may threat stability and security in society, endangered social and economic development and also the political stability. This can also destructed democratic value and morality since corruption gradually may become culture. Indonesia is one of the nation that face serious problem in corruption. The corruption cases in all level of birocrarcy, court administration, and private sector have plunged Indonesia not only in national level but also in the eye of international community. Establishment of Act Numebr 31 Year 1999 on Eradication Against Corruption as changed by Act Number 20 Year 2001 on Eradication Against Corruption, based on the though that corruption is such a deep problem, that have gnaw almost all aspect of nation life. Therefore prevention and handing out of corruption shall not used conventional way, but indeed use an extraordinary way.

Corruption caused the state financial loss. This is eventually will lead to loss of all Indonesia peoples. Hence the state financial loss shall recover so nation development my keep run, law enforcement against corruption shall also bring back the state asset from corruptor. Law enforcement officers may disposed state asset from corruptor based on court verdict. However a problem emerged when corruptor escape from the law process, thereby executor officers can not executed states assets. This issue can be handle with in absentia court, that is a procedural law that allowed judge to proced a criminal case in court without the accused presence. Indonesia procedural law, as enumerated in Act Number 8 Year 1981 do not firmly arranged in absentia court. However this can be implied from article 196 subsection (1) that state :"The Court verdict a case with the accused presence except in a case of another dictates by an act.Even in absentia court do not frimly stated in this article, but from words of the article that said : "...except in a case of another dictates by an act", it is can be interpreted that as long as an act allowing in absentia court that it can be used in an criminal procedural law. Act Number 31 Year 1999 as changed with Act Number 20 Year 2001 regarding Eradication Against Corruption have allowing in absentia court in case of corruption as stated in article 38 subsection 1: "in case of the accused have lawfully called and do not attend the court without any lawfull reason than the case can be examined and verdicted without presence of the accused"

This research will analized the legal politic of Act Number 31 Year 1999 as changed with Act Number 20 Year 2001 regarding Eradication Against Corruption particularly the policy to recover state assets from corruptor.

\section{METHOD}

Type of method in this research is a normative legal research. Soemito described that normative legal research ia a library study. ${ }^{3}$ This research used two approach that are statute approach and conceptual approach. Statute approach was by using rules enumerated in acts and its interpretation, while conceptual approach by using the concept of in absentia by scholar.

Data used in this research only secondary data. This is as stated by Amiruddin and Zainal Asikin that for the normative legal research, know only secondary data that consist of primary law data, secondary law data and tertiary law data. ${ }^{4}$ Primary law data consist of Acts that are UUD 1945, TAP MPR, Act and Government Regulation. Secondary law data consist of research

\footnotetext{
${ }^{2}$ Mohammad Irfan. H.Israfil. "Baja Value Sanction as an Alternative Punishment for The Corruptors in Bima Disrict NTB Province”, ULREV, Volume 1, Issue 1, April 2017, p. 41-42.

${ }^{3}$ Soemitro. Ronny Hanitijo. (1990). Metodologi Penelitian Hukum dan Jurimetri. Jakarta:GhaliaIndonesia, p.11.

${ }^{4}$ Amiruddin.Zainal Asikin. (2016). Pengantar Metode Penelitian Hukum. Cet. 6, Jakarta:PT. Rajagrafindo Persada, p.163.
} 
result in an journal article and text book. Tertiary law data consist of language dictionary and Law Dictionary. Data collected through library study, that is by collecting legal material from literature in library. Those library are faculty of law library, University of Mataram Library and Library of NTB Province. Beside those library, data also collected by accessed web of Indonesia Journal. Those legal material then analyzed qualitatively, that is by using rules and its interpretation and scholar opinion to build researcher opinion regarding legal issue.

\section{DISCUSSION}

\section{Concept of In Absentia in Corruption}

In absentia court is a trial court process without presence of the accused, from the examination process up to court verdict. As a process to prosecute person without their present, then this process taken in a particular and urgent situation. ${ }^{5}$ Law do not legalized in absentia court in a regular procedural and short procedural. Absence of the accused in a trial caused the examination of a criminal case can not proceed. The importance of an accused presence stipulated in article 154 that arranged how to present an accused in a trial.

The procedural started from : ${ }^{6}$

a. Head of trial ordered accused to come in a trial court;

b. If an accused do not presence in a trial, head of trial examined whether the accused have lawfully called.

Absence of an accused in a trial may occur because of some possibilities, first the accused do not called lawfully; head of trial withhold the trial and ordered the public prosecuter to called the accused once more to presence next trial; second absence of the accused in a trial without any lawfull reason even the accused have lawfully called.

Main problem appear for the accused that proceed in absentia trial that there are no space for self defense in that trial process. Hence every one have a right to self defense this may be an issue. In an in absentia trial, lawyer of the accused forbid to come in the room trial based on Letter of Indonesian Supreme Court Number 6 Year 1988 Regarding Lawyer that accept authority from Accused in absentia.

According to Leden Marpaung, court examination without accused presence is an exception. Exception to an act not only accepted in Indonesia, but have a general characteristic accepted internationally. This referred as No Rule Without Exception. ${ }^{7}$ Principle of Presence of Accused in a criminal court is a human rights manifestation. Defend every right and freedom, property and honour are human rights. As long as there are no court verdict that already legally binding, then the accused shall consider not guilty. This is accord with presumption of innocence principles.

Dwiyanto Hartono stated that $:^{8}$

“...in absentia trial opened two opportunities; first it will showed supremacy of law in every criminal action, second it will be an arrogance of law officer who proceed in absentia trial. Because practically it hard for the in absentia trial to showed fact and objective finding that can delivered fair and independence judgement.

\footnotetext{
${ }^{5}$ Toetik Rahayuningsih. Indra Wahyuni. Hukum Acara Tindak Pidana Korupsi dalam Hukum Anti Korupsi. p.427.

${ }^{6}$ M. Yahya Harahap. (2006). Pembahasan Permasalahan Dan Penerapan KUHAP (Pemeriksaan Sidang Pengadilan, Banding, Kasasi, dan Peninjauan Kembali). Cet. VIII. Jakarta: Sinar Grafika. p. 111.

${ }^{7}$ Leden Marpaung. (2011). Proses Penanganan Perkara Pidana Di Kejaksaan dan Pengadilan Negeri Upaya Hukum dan Eksekusi. Cet. 2, Jakarta: Sinar Grafika Offset. p. 95.

${ }^{8}$ Dwiyanto Prihartono. (2003). Sidang Tanpa Terdakwa: Dilema Peradilan In Absentia dan Hak Asasi Manusia. Yogyakarta : Pustaka Pelajar Offset. p.34.
} 
There are three different view among legal scholar that influenced legality of in absentia court in corruption cases, that are: ${ }^{9}$

(1)View that consider examination before the court absolutely need presence of the accused. This view extremely denied in absentia trial. Articles as bases for this view are Article 145 subsection (5) , Article 154 subsection (5), Article 155 subsection (1), Article 203 and Article 205. Comprehension of those articles that is imposible a case examined and prosecuted without the accused presence. Investigator will face a substansial difficulties in arranged police investigation report because the absence of investigation object.

(2)View that on the reason of state asset recovery in corruption cases in time of transition, then articles in Act redarding Eradicating Against Corruption shall given breakthrough. Theoretically this can be justify on a reason to process legal finding (rechtvinding) on a cases that do not have a firmly rule. Refference for this standpoint is article 38 (1) of Act Regarding Eradicating Against Corruption that placed corruption crime as an extraordinary crime therefore lawenforcement of this crime beyond ordinary procedural as arranged in KUHAP. This is an exceptional procedure with purpose to save state assets. Principally exception in a procedural law is an extraordinary procedure, such as procedure in a human rights grave breahes case that may override non retroactive principle. Other extraordinary procedure are authority of authorney general to override case, including in absentia trial. Exception in an in absentia trial for corruption cases due to it regards with official position or known as occupation official position that is a crime that implementation of which shall required an official position or particular job protected by the law allowing the perpetrator as a powerfull person that difficult to reach.

(3)The most moderate view, that is an in absentia trial may proceed, but in practice it still have to get through a maximized normal working process. This view consider that two opinion before are legal product alike thus those two need to be mixed to become a new strong postulate. Moderate view consider that in absentia court basically is a law mandate that its implementation shall accord with the rule applied.

In absentia court in corruption case have a connection with human rights protection, that is particularly the convected rights. Since In absentia trial do not give a chance for the convected to get a fair trial such as those enumerated in the Criminal Procedures Code, those are: right of the convected to present in the trial; absence of the convivted ensued to non compliance of the right to equality before the law without any discrimination, the right for presumption of innocence. Those rights not only ensure by the criminal procedures code and Indonesia law but also ensure by international document. This is as stated as followed:

Peradilan in absentia dalam perkara Tindak Pidana Korupsi dan kaitannya dengan HAM terdakwa adalah dimana pada dasarnya dengan diadakannya peradilan in absentia tidak menghargai hak-hak dari terdakwa dalam proses hukum yang adil (due process of law) sebagaimana yang terdapat dalam KUHAP hak-hak yang dimaksud adalah hak kehadiran terdakwa dalam persidangan, ketidakhadiran terdakwa berakibat tidak terpenuhinya hak atas perlakuan yang sama di muka hukum tanpa diskriminasi apapun (equality before the law), hak atas praduga tak bersalah (presumption of innocence) dan juga hak untuk dibantu oleh penasehat hukum. Hak- hak tersebut selain dijamin dalam KUHAP juga sudah dijamin dalam peraturan perundang-undang di Indonesia dan dokumen-dokumen Internasional. ${ }^{10}$

\footnotetext{
${ }^{9}$ Ibid. p. 26-27.

10 Suriadi Harianja,” Peradilan In Absentia Pada Perkara Tindak Pidana Korupsi Dalam Perspektif HAM Terdakwa”, UNNES LAW JOURNAL, Vol.2, No. 1, Juli 2013, https://journal.unnes.ac.id/sju/index.php/ulj,[Accesed January 15, 2019 ], p. 42.
} 


\section{Legal Politic of Assets Recovery by In Absentia Trial in Indonesian Act Regarding Eradi- cating of Corruption.}

Satjipto Rahardjo defined legal politic as an activity to chose and a way to achieve a particular social and legal purpose in society. ${ }^{11}$ According to Soedarto in his book titled "Hukum dan Hukum Pidana", defined legal politic as a policy of State through its authorized body to set the required rules which is expected to be used to express what is contained in the community and to achieved what is aspired. ${ }^{12}$ Legal politic investigate what changes are made in the law that currently prevail, whether those law are inline with the needs of the community. Legal politic will determine which law needs to be promulgated; which law need to be amended or which law needs to be abolished.

Substitution of the legislation signifies the operation of legal politics. The first legislation for corruption is the Law Number 3 of 1971 concerning the Eradication of Corruption Crimes. Furthermore, after the reform movement, Law Number 31 of 1999 concerning the Eradication of Corruption Crimes which has been amended by Law Number 20 of 2001 concerning Amendment to Law Number 31 of 1999 concerning the Eradication of Corruption Crime, the two laws are still valid until now. These changes have overall illustrated the renewal of criminal law in combating corruption. The law can be seen that the drafters of the law systematically formulate criminal acts of corruption. ${ }^{13}$

The direction of the policy to eradicate corruption, collusion and nepotism is regulated in the Decree of the People's Consultative Assembly of the Republic of Indonesia Number VIII / MPR / 2001 concerning Recommendations on the Direction of the Policy to Eradicate and Prevent Corruption, Collusion and Nepotism. This decree was born on the basis of the consideration that the problems of corruption, collusion and nepotism that hit the Indonesian nation were very serious, and were extraordinary crimes and destabilized the joints of the life of the nation and state. The decree was also born on the basis of consideration of the renewal of commitment and political will to eradicate and prevent corruption, collusion and nepotism requiring accelerated steps.

Based on these considerations, one of the Directions for the Eradication and Prevention of Corruption, Collusion and Nepotism is "Accelerating the legal process of government apparatus, especially law enforcement officials and state administrators who are suspected of practicing corruption, collusion and nepotism, and administrative actions can be taken to expedite the legal process. "In addition, it is also recommended to take more serious legal action against all corruption cases, including corruption that has occurred in the past, and for those who have been proven guilty of being sentenced to the most severe.

Law enforcement against corruption should not only emphasize the imposition of law on the perpetrators but also efforts to restore State assets. There is a balance between the imposition of sentences and the return of State assets. The return of State assets is one of the important parts in law enforcement against corruption, collution and nepotism crimes. As for relating to the in absentia court, in prosecuting corruption, the judiciary in absentia can be seen as an effort to accelerate the legal process and the imposition of criminal law against the perpetrators. This is as stated in the explanation of Article 38 (1) of the Act Eradicating Against Corruption, which states as follows: The provisions in this paragraph are intended to save the country's wealth so that without the presence of the accused, cases can be examined and decided by the judge. Therefore In absentia court can be said to be in harmony with the direction of the policy of

\footnotetext{
${ }^{11}$ Satjipto Raharjo.(2000). Ilmu Hukum. Bandung: Citra Aditya Bakti, p. 35

${ }^{12}$ Soedarto.(1986).Hukum dan Hukum Pidana. Bandung: Alumni, p. 151

${ }^{13}$ Respati Nadia Putri,Perkembangan Peraturan dan Peradilan Dalam Pemberantasan Tindak Pidana Korupsi di Indonesia, p.10
} 
Eradicating and Preventing Corruption, Collusion, and Nepotism as confirmed in the Decree of the People's Consultative Assembly of the Republic of Indonesia Number VIII / MPR / 2001 concerning Recommendations on the Direction of the Policy to Eradicate and Prevent Corruption, Collusion and Nepotism

In absentia court is one of the efforts in the process of accelerating law enforcement, asside to providing legal certainty to the defendant himself, also providing legal certainty for the return of State assets seized by corruptors. Considering the execution process of returning the assets will only occur after a court ruling that has permanent legal force, the judiciary in absentia is therefore a legal breakthrough that can speed up the process of examination in court. In absentia court in the Indonesian criminal law system is a lex specialis, since in absentia court may proceed only the perpetrators for certain cases, namely terrorism, fisheries crime, money laundering crime, and economic crime.

The criminal justice system in Indonesia generally requires the presence of a defendant in the trial. The articles that are referred to are the articles in the Criminal Procedure Code which include Article 145 paragraph (5), Article 154 paragraph (5), Article 155 paragraph (1), Article 203 and Article 205. Understanding of the provisions of these articles is it is impossible for a case to be examined and tried without the presence of the defendant. That the investigators will experience substantial difficulties in compiling the examination, because of how it might be carried out without the object being examined. The absence of the defendant in the trial is something that can prevent the process of hearing the trial. Without the presence of the defendant in the trial hearing the purpose of the hearing is to find or at least close to the material truth cannot be realized. The hearing of the trial was unilateral because there was no defendant during the hearing in court.

Although the Criminal procedure Code does not strictly regulate the provisions of the inabsentia trial, whether in the provisions of the clauses or their explanations, the provisions of Article 196 paragraph (1) and Article 214 paragraph (1) and (2) of the Criminal Procedure Code allow in absentia court. Article 196 sets out the following: The Court decides on the case with the defendant's presence except in the case of law have regulated otherwise. The sound of the provisions in Article 196 stipulates that "... except in the event that this law specifies otherwise.”, Which may be the basis of special law, including the Act No. 31 of 1999 jo. Law Number 20 Year 2001 on the Eradication of Non-Criminal Corruption to use judicial in absentia. Along the specific Law regulates in absentia then the trial can be done in absentia.

For criminal acts of corruption, the trial in absentia is regulated in the provisions of Article 38 paragraph (1) of Law Number 31 of 1999 as amended into Law Number 20 of 2001 concerning the Eradication of Corruption Crime which states as follows: In the event the defendant has been summoned legally and not present at the court session without a valid reason, the case can be examined and decided without defendant presence. The legislation governing the in absentia court as mentioned above is a special statutory regulation, with its specific nature and based on the principle Lex Specialis Derogate Lex Generalis, the provisions of the articles in this particular statutory regulation exclude general legislation (Lex Generalis as regulated by the Criminal Procedure Code).

The exception to the in absentia examination is that corruption is considered a crime that is categorized as a serious crime. Since this crime is not an ordinary crime, so the solution must be done in extraordinary procedure. If using ordinary procedure, there will be obstacles to confront the defendant in front of the trial so that he cannot penetrate the crime network. Therefore in eradicating corruption, the legislators open a space that deviates from the specific legal tradition that allows the implementation of the trial in absentia to be validated by law. This is also in line with the policy direction in the Decree of the People's Consultative Assembly of 
the Republic of Indonesia Number VIII / MPR / 2001 which emphasizes the acceleration of legal processes in criminal acts of corruption.

In absentia court is not only seen in an effort to accelerate the legal process but also to minimize state losses through the return of state assets. By speeding up the legal process, it can immediately get a court ruling which is the basis for executing State money and assets from corruption. With the decision of the court in absentia to restore losses, the State has a clear legal basis as a form of legal certainty.

One element in corruption is the existence of state financial losses. Law Number 31 Year 1999 jo. The Law Number 20 Year 2001 concerning Eradication of Corruption Crimes, stipulates the policy that State financial losses must be returned or replaced by perpetrators of corruption. Philosophically, the legal breakthrough in combating corruption is not only intended to give a deterrent effect to the perpetrators. He is also oriented to the effort to return State assets looted by corruptors. This reason is the reason behind the birth of the reformation legislation. ${ }^{14}$

Returning corruption assets is a law enforcement system that requires the existence of the process of removing the rights to the assets of the perpetrators of the victim's country by eliminating the assets of the perpetrators in civil or criminal manner, which can be carried out in confiscation, freezing, and seizure, both in local, regional and international competencies so that wealth can be returned to the State (victim) that is legitimate. ${ }^{15}$

The regulation on legislation has regulated compensation for state finances, known as substitute money. Settlement of State losses is carried out to restore State assets lost or reduced due to criminal acts of corruption. Arrangements regarding substitute money. Arrangement regarding substitute money in Law Number 31 of 1999 in Article 18 paragraph (2) which determines that:

"Jika terpidana tidak membayar uang pengganti paling sebagaimana dimaksud di dalam ayat (1) huruf b paling lama dalam waktu 1 (satu) bulan sesudah putusan pengadilan yang telah memperoleh kekuatan hukum tetap, maka harta bendanya dapat disita oleh jaksa dan dilelang untuk menutupi uang pengganti tersebut."

The return of losses on State finances is an obligation that must be carried out by the perpetrator as stipulated in the law. The return of this state finance must be prioritized to restore the state's economy.

\section{CONCLUSSION}

In absentia court in corruption crimes law enforcement is a procedural law breakthrough in order to return state's assets. This have enumerated in Indonesian Law concerning Eradication Against Corruption. Eventhough the Decree of the People's Consultative Assembly of the Republic of Indonesia Number VIII / MPR / 2001 do not clearly affirmed state's assets recovery, This is in line with the legal politics in the decree which emphasizes the acceleration of legal processes in criminal acts of corruption.

\section{BIBLIOGRAPHY}

\section{Books}

Amiruddin dan Zainal Asikin.(2016). Pengantar Metode Penelitian Hukum, Cet. 6, Jakarta: PT. Rajagrafindo Persada.

Ali, Mahrus. dalam Jekson Kasehug, Hak Menuntut Kerugian Keuangan Negara Setelah Putusan Bebas Dalam Tindak Pidana Korupsi, Jurnal Lex dministration, Vol III/No.1/ Jan-Mar/2015Diakses dari http//ejournal.unsrat.ac.id/index.php/administratum/

\footnotetext{
${ }^{14}$ Ibid, p. 30.

${ }^{15}$ Indriayanto Seno Adji. (2009). Korupsi dan Penegakan Hukum. Jakarta:Diadit Media, p. 149-150.
} 
article/download/7082/6595, 3 Januari 2018.

Harahap,M.Yahya.(2006). Pembahasan Permasalahan Dan Penerapan KUHAP (Pemeriksaan Sidang Pengadilan, Banding, Kasasi, dan Peninjauan Kembali), Cet. VIII, Jakarta: Sinar Grafika.

Hartono, Sunaryati. (1991). Politik Hukum Menuju Satu Sistem Hukum Nasional, Bandung:Alumni.

Mahfud MD. (2010). Membangun Politik Menegakkan Konstitusi, Jakarta, Raja Grafindo Persada.

Mahfud MD. (2009).Politik Hukum Di Indonesia,Jakarta, Raja Grafindo Persada.

Marzuki, Mahmud. (2016). Penelitian Hukum, Kencana Prenda Media Group, Jakarta.

Madril, Oce \& Hasrul Halil. (2011).Pengertian Korupsi dalam Hukum Anti Korupsi, Bandung: USAID.

Marpaung, Leden.(2011). Proses Penanganan Perkara Pidana Di Kejaksaan dan Pengadilan Negeri Upaya Hukum dan Eksekusi, Cet. 2. Jakarta.: Sinar Grafika Offset.

Raharjo, Satjipto. (2000). Ilmu Hukum , Bandung: Citra Aditya Bakti.

Rahayuningsih, Toetik \& Indra Wahyuni, Hukum Acara Tindak Pidana Korupsi dalam Hukum Anti Korupsi.

Simarmata, Jorawati. (2016) Politik Hukum Restrukturisasi Pembentukan Perangkat Daerah Pasca Revormasi ( Sekilas Tanggapan Terhadap Peraturan Pemerintah Nomor 18 Tahun 2016 Tentang Perangkat Daerah), Kantor Wilayah Kementrian Hukum dan Hak Asasi Manusia Riau, Pekanbaru.

Soedarto. (1986). Hukum dan Hukum Pidana, Bandung:Alumni.

Syaukani, Imam dan A.Ahsin Thohari. (2006). Dasar-dasar Politik Hukum, Jakarta: PT. Raja Grafindo Persada.

Soemitro, Rinny Hanitijo. (1990). Metodologi Penenlitian Hukum dan Jurimetri. Jakarta:GhaliaIndonesia.

Wahjono, Padmo.(1986). Indonesia Negara Berdasarkan atas Hukum, cet.II, Jakarta: Ghalia Indonesia.

Wahjono, Padmo. (1991). Menyelisik Proses Terbentuknya Perundang-undangan, Forum Keadilan,No. 29 April 1991.

\section{Journal Articles}

Harianja, Suriadi. (2013). Peradilan In Absentia Pada Perkara Tindak Pidana Korupsi Dalam Perspektif HAM Terdakwa, UNNES LAW JOURNAL, Vol.2, No. 1, Juli 2013, https:// journal.unnes.ac.id/sju/index.php/ulj,diakses tanggal 15 Januari 2019.

Nadia Putri, Respati. (2017). Perkembangan Peraturan dan Peradilan Dalam Pemberantasan Tindak Pidana Korupsi di Indonsia::///D:/ZONA\%20EKSLUSIF\%20TITIN/ ZONA\%20KULIAH/S2/SEMESTER\%201/SEJARAH\%20DAN\%20POLITIK\%20 HUKUM/POLITIK\%20HUKUM/Perkembangan_Peraturan_dan_Peradilan_Dal. $p d f$ (Diakses tanggal 3 Januari 2018).

Mohammad Irfan. H.Israfil. "Baja Value Sanction as an Alternative Punishment for The Corruptors in Bima Disrict NTB Province”, ULREV, Volume 1, Issue 1, April 2017. 